\title{
Article \\ Wind and Solar Power Plant End-of-Life Equipment: Prospects for Management in Ukraine
}

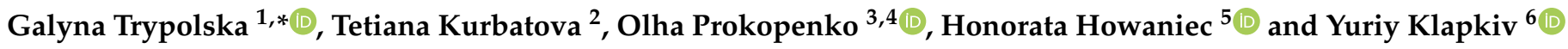 \\ 1 The Institute for Economics and Forecasting, National Academy of Sciences of Ukraine, P. Myrnogo St. 26, \\ 01011 Kyiv, Ukraine \\ 2 Department of International Economic Relations, Sumy State University, Rimsky-Korsakov St. 2, \\ 40007 Sumy, Ukraine; t.kurbatova@macro.sumdu.edu.ua \\ 3 Economics Department, Collegium Mazovia Innovative University, Sokołowska St. 161, \\ 08-110 Siedlce, Poland; olha.prokopenko@eek.ee \\ 4 Estonian Entrepreneurship University of Applied Sciences, Suur-Sõjamäe St. 10a, 11415 Tallinn, Estonia \\ 5 Faculty of Management and Transport, University of Bielsko-Biala, Willowa St. 2, \\ 43-309 Bielsko-Biala, Poland; hhowaniec@ath.bielsko.pl \\ 6 Department of Insurance, University of Lodz, Pres. Gabriela Narutowicza St. 68, 90-136 Lodz, Poland; \\ jurij.klapkiv@uni.lodz.pl \\ * Correspondence: g.trypolska@gmail.com
}

check for updates

Citation: Trypolska, G.; Kurbatova, T.; Prokopenko, O.; Howaniec, H.; Klapkiv, Y. Wind and Solar Power Plant End-of-Life Equipment: Prospects for Management in Ukraine. Energies 2022, 15, 1662. https://doi.org/10.3390/en15051662 Academic Editor: Joshua M. Pearce

Received: 4 January 2022

Accepted: 18 February 2022

Published: 23 February 2022

Publisher's Note: MDPI stays neutral with regard to jurisdictional claims in published maps and institutional affiliations.

Copyright: (C) 2022 by the authors. Licensee MDPI, Basel, Switzerland. This article is an open access article distributed under the terms and conditions of the Creative Commons Attribution (CC BY) license (https:// creativecommons.org/licenses/by/ $4.0 /)$.

\begin{abstract}
The Ukrainian renewable energy sector has demonstrated a significant increase in its renewable power capacity, especially for solar and wind power plants. Decommissioning the end-oflife equipment in Ukraine has not yet taken place, but it is only a matter of time. With this in mind, this paper assesses the quantities and the market values of the materials that could potentially be recovered from used solar and wind power plants, and it estimates the impact of their decommissioning on employment in Ukraine. It has been estimated that approximately $8.9 \mathrm{GW}$ of solar power plants, and 3.6 GW of wind power plants, will be decommissioned from 2044 to 2059, and that the cost of the raw materials recovered could reach EUR 421.4 million and EUR 124.6 million in 2021 prices, respectively, compared to the decommissioning costs of EUR 240.1 million and EUR 49.1 million, respectively. Decommissioning renewable power plants will require the creation of new jobs, including 11.6 thousand in the solar industry, and 2.8 thousand in the wind sector. It is essential to amend the legislation in Ukraine, particularly Directive 2012/19/EU, to introduce the principle of the extended producer responsibility to ensure the efficient recycling of renewable power plant end-of-life equipment in Ukraine in the future.
\end{abstract}

Keywords: renewable energy; employment; end-of-life equipment; recycling; circular economy; finance; Ukraine

\section{Introduction}

Over the last 20 years, the role of renewable energy in the energy balance, globally, has been increasing. The shares of solar and wind energy worldwide are expected to be $20 \%$ and $16 \%$, respectively, of the total energy supply in 2050 , compared to $1 \%$ in 2020 [1], which will be achieved primarily through the installation of new generating capacities. Correspondingly, the amount of wind and solar power plant end-of-life (EOL) or waste equipment will increase [2]. In many countries, the issue of EOL equipment and its recycling is already being actively discussed, specific technological solutions are being developed, and roadmaps for recycling are being compiled [3]. The International Renewable Energy Agency (IRENA) and the International Energy Agency Photovoltaic Power Systems Programme (IEA-PVPS) forecast that a substantial amount of wind and solar power plant EOL equipment will appear in the early 2030s, and that, by 2050, it will be 60-78 million tons. The countries with the most significant amount of solar power plant EOL equipment will be China, Germany, and Japan in 2030, and China, the United States, 
and Japan in 2050. Markert et al. [4] determine that "recycling solar is the way to recover the materials, but the costs and benefits of recycling are mainly unknown". They found that the private cost (i.e., in this case, the cost the company bears to get rid of the used solar equipment that is no longer needed) of the EOL equipment management of the crystalline silicon photovoltaic (PV) module is USD $6.7 / \mathrm{m}^{2}$, half from its transport, and the other half from the landfill disposal, and the cost of the actual recycling process is only USD $0.3 / \mathrm{m}^{2}$, whereas the value of the recovered materials is USD $13.6 / \mathrm{m}^{2}$. Chowdhury et al. [5] state that solar panels contain some hazardous waste. Their study reviews the current status of solar panel waste recycling, recycling technology, waste management, recycling policies, and the economic aspects of recycling. Dominguez and Geyer analyzed the PVwaste generation of 277 solar installations in Mexico under different scenarios, including as market shares in PV module technology, and as recycling yields for metals and the metal composition of transformers, which is drawing the attention of policymakers and stakeholders to the potential benefits that recycling may bring [6]. Mathur et al. analyzed the decommissioning process of solar PV modules in Australia and found that it is often premature, which makes it necessary to develop a policy for sustainable EOL management because the waste management of decommissioned PV plants takes place in a "policy vacuum" [7]. Lunardi et al. indicate that most decommissioned PV modules go to landfills because of the insufficient economic feasibility of the recycling process and the poorly established regulation in many countries globally [8]. As is expected, the recycling of EOL solar PV modules causes minimal environmental impact compared to landfill disposal or incineration. Overall, EOL equipment decommissioning and its environmental impact, especially with solar PV modules, is relatively well described in the scientific literature. Alsubal et al. describe the waste management strategies for EOL wind turbines in Malaysia [9]; however, feasibility studies and the costs and financial parameters remain scarce, as is confirmed by Invernizzi et al. [10].

The primary approach to the global problem of wind energy and PV EOL equipment should be recycling [11]. The IRENA and the IEA-PVPS estimate that using recycled solar panels alone can save USD 450 million, according to 2016 prices, by producing 60 million new solar panels, or $18 \mathrm{GW}$ of new solar power plant capacity. Similarly, by 2050, it may be possible to save USD 15 billion and to produce 2 billion panels, or $630 \mathrm{GW}$, of new capacity. Almost $96 \%$ of the raw materials obtained from decommissioned solar panels can be recycled (i.e., the recycling efficiency is $96 \%$ ), and numerous studies are currently underway to improve the recycling efficiency [12]. Globally, solar panels are already being successfully recycled. The recycling and processing market in the European Union amounted to USD 49.1 million in 2020, and its growth is expected to be $19 \%$ annually up to 2027 [13]. In 2019, there were 6000 tons of PV waste in France; by 2025, there will be 1 million tons of used PV panels in the European Union to be dismantled and disposed of in the future. By 2050, the European Union expects nearly 10 million tons of solar power plant waste, from which 300 thousand tons of pure silicon, and $75 \mathrm{GW}$ of new solar power plant capacity can be obtained, even with the current technologies [13]. The estimation of the solar PV and wind plant installation might be reconsidered by taking into account the role that renewables play in green hydrogen production, which would offer substantial environmental advantages $[9,14,15]$.

Wind power plant equipment has a shorter service life, and, in addition, wind turbines of lower capacities tend to be replaced by more powerful equipment (up to $4.2 \mathrm{MW}$ per wind turbine). EOL wind power equipment is more challenging to recycle, especially the old blades, because wind turbines are usually big. The fiberglass blades (strong and wind-proof) are pretty hard to crush for further reuse or recycling, and the long-distance transportation of turbine elements is costly. Nevertheless, in general, up to $90 \%$ of the raw materials of wind turbines (steel, concrete) can be recycled. The blades are currently $42-43 \%$ recyclable, but research is underway to develop $100 \%$ decomposable blades (ZEBRA: the Zero wastE Blade ReseArch project) [16]. However, even the present blades can be used for cement manufacturing, which results in $27 \%$ lower $\mathrm{CO}_{2}$ emissions, and $13 \%$ lower water 
consumption compared to traditional cement production methods [17]. As of 2021, about $80 \%$ of dismantled turbines are reused in other countries, and only $20 \%$ are recycled [18].

The available scientific thought in Ukraine focuses on the abundant energy potential of renewables and on the comparison of the legislation and policies in place to deploy renewables in Ukraine and its neighboring countries. Nykyruy et al. found that, with the similar geographic and climatic conditions in Ukraine and Poland, there is similar research interest in renewables, such as photoelectricity or thermal electricity. However, Poland's attention to bioenergy deployment is significantly greater than that of Ukraine's [19]. Kharlamova et al. found that investing in renewables is part of the country's "smart" policy, which enhances the employment rate in the industry [20]. Kolosok et al. discovered the volatility of the production and consumption of electricity from renewables in 2019, which affect Ukraine's energy security [21]. Agapova et al. studied the optimal location of new RES facilities in the Kharkiv region of Ukraine using the cartographic approach [22]. Child et al. investigated the role of energy storage technologies in 100\% renewable energy sources (RES) by 2050, stating that the energy system needs to contain up to $139 \mathrm{GWh}$ of batteries, 9 GWh of pumped hydro storage, and up to 18,840 GWh of gas storage [23]. Kuzior et al. surveyed the public perception of renewable energy in Ukraine and identified the readiness of the population to apply renewables [24].

The abovementioned literature indicates that the recent publications on renewable energy in Ukraine do not consider the issue of EOL equipment, which justifies the respective focus on Ukraine because its experience is relevant for countries with expanding RES.

This paper aims to consider the possibilities of managing solar and wind power plant EOL equipment within the internal waste recycling in Ukraine. The main areas of research that determine the novelty of this paper relate to: the evaluation of the feasibility of decommissioning and recycling wind and solar power plant EOL equipment; the assessment of the impact of the need for solar and wind power plant decommissioning on employment in Ukraine; and the review of the best world legislative practices with regard to managing solar and wind power plant EOL equipment, as well as a proposal for potential legislative changes in this field for Ukraine.

\section{Materials and Methods}

RES are identified as one of the priority areas of Ukraine's energy sector, as is confirmed in leading strategic documents, particularly the Second Nationally Determined Contribution of Ukraine [25], and the National Economic Development Strategy until 2030 [26]. Renewable energy equipment, in particular solar and wind power plants and others, has an assigned lifetime, after which the equipment must be dismantled, recycled, and disposed of (either in the country of use or any other). Despite the financial and regulatory obstacles to developing renewable energy in Ukraine, this country is gradually increasing the installed capacities of RES, especially solar. However, the disposal of solar and wind power plant EOL equipment in Ukraine has been considered only by relevant associations (e.g., the European-Ukrainian Energy Association) and is not yet reflected in the legislation.

According to the State Agency on Energy Efficiency and Energy Saving of Ukraine, as of July 2021, the overall installed capacity of solar PV modules reached $7284 \mathrm{MW}$, and that of wind power plants reached $1464 \mathrm{MW}$ in Ukraine [27]. The official data on the installed capacities at the end of 2020 are shown in Figure 1.

The average service life of a solar panel is about 20-35 years, and that of a wind turbine is 25 years. The insalubrious waste from windmills is residual engine oil, as well as heavy metals that contaminate the soil. 


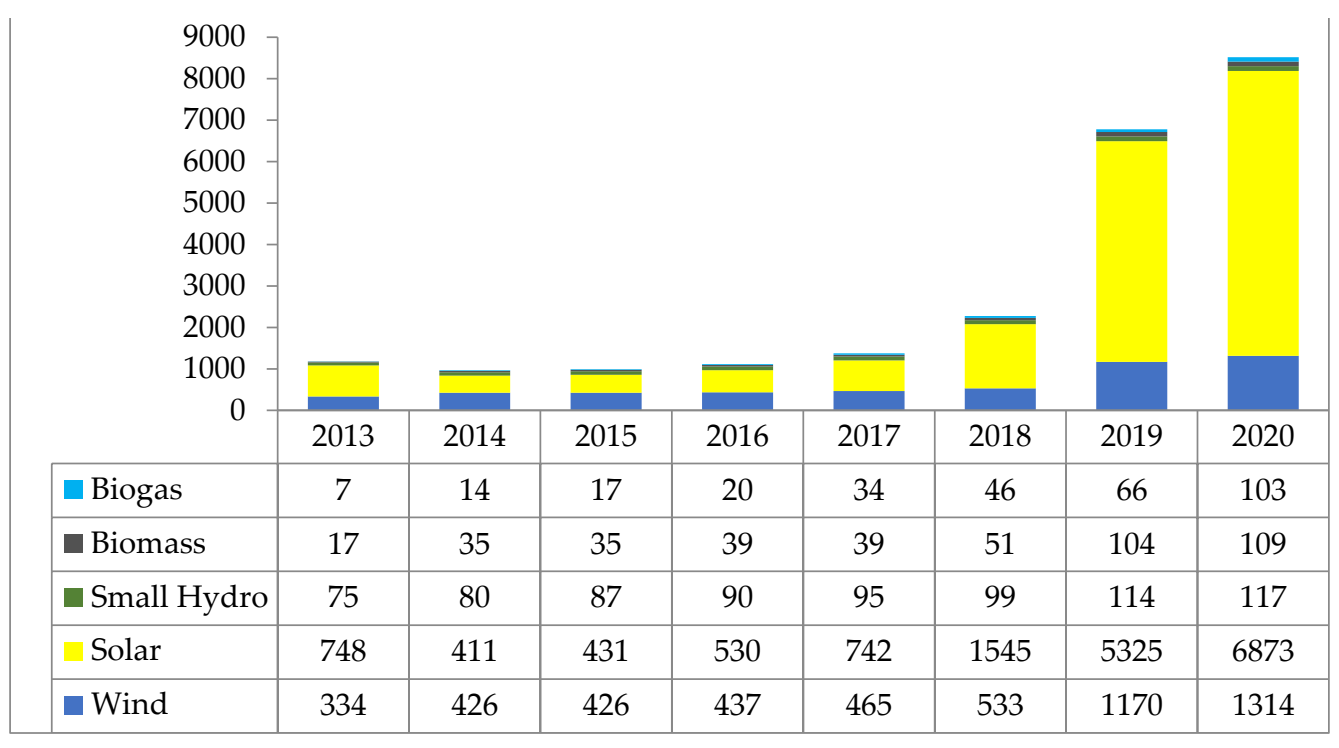

Figure 1. Installed capacities (in MW) of electricity generation facilities based on renewable energy sources in Ukraine [27].

Some technologies allow for the use of solar panels for 40 years, but these are relatively new. New panels are used for solar power plants in Ukraine and those previously in use [28], especially in the EU countries. Accordingly, their service life is even shorter. Almost $90 \%$ of the solar panels on the market are made of crystalline silicon. Solar panels consist of glass $(71 \%$ of the total mass), polymers $(12 \%)$, aluminum $(8 \%)$, silicon $(3 \%)$, copper $(1 \%)$, silver $(0.1 \%)$, and other elements [13]. Silver, lead, and some polymers are hazardous waste, which is difficult to recycle. Silver is not considered the most hazardous metal; it is used for many industrial purposes and the human body can tolerate it in small amounts, but it may cause a permanent skin condition if these amounts are exceeded. It is highly toxic to fish, causing problems with their reproductive systems and contributing to ecosystem collapse [29]. Silicon and aluminum can be processed centrally, which enables economy of scale. It is advisable to separate glass and aluminum from other components and to grind them as close as possible to the place of disassembly in order to reduce transport costs and reduce harm to the environment. To remove these elements, the panel must be dismantled. Thin-film panels are composed of $98 \%$ glass, aluminum, and polymers, and $2 \%$ hazardous zinc, copper, and semiconductors (gallium, selenium, cadmium, tellurium, and lead) [2]. They contain nearly 500 times less silicon than crystalline silicon panels and are thus cheaper.

Below, we assess how many solar panels and wind turbines should be decommissioned and disposed of in the future. To calculate this, we consider the data on the installed capacity since 2014 because part of the Ukrainian power generation capacity is located in the Autonomous Republic of Crimea, which is annexed by the Russian Federation and in the temporarily occupied East Ukraine, and these capacities do not generate electricity. The other specific assumptions were as follows:

- We assume that only new solar panels are used in Ukraine. This is not entirely true, but the share of panels used in the Ukrainian market is unknown. For further calculation, we assume that a solar panel is used for 30 years (the so-called "regular loss") [2], and a wind turbine for 25 years. The older models of wind turbines had service lives of 20 years. In addition, new wind turbines are gradually being improved over time, so there is the problem of updating the production equipment in the existing wind power plants;

- The weight of a 250-W PV panel is $19 \mathrm{~kg}$, and the weight of a 320-W panel is $26 \mathrm{~kg}$ [30];

- In Ukraine, it is assumed that $90 \%$ of the capacity of crystalline silicon panels, and $10 \%$ of the capacity of thin-film panels, are used; 
- $\quad$ By considering the significant skew in the electricity generation from RES towards solar power plant capacity, and by taking into account the intention to move to the distributed quotas of the state support system that energy producers should obtain during the auctions, we assume that the new capacities will be installed in volumes approximately corresponding to those announced (but not officially approved) by the Ministry of Energy of Ukraine to support quotas by 2025. The Ministry expected that 365 MW of RES capacity would be put into operation in 2021, and that the quotas should increase from $420 \mathrm{MW}$ in 2022 to $570 \mathrm{MW}$ in 2025. An extrapolation of the existing trends with regard to the installation of the new capacities and considering these support quotas may achieve a $21 \%$ share of electricity generation from RES by 2030 [30]. Accordingly, the capacities shown in Figure 2 will be added annually.

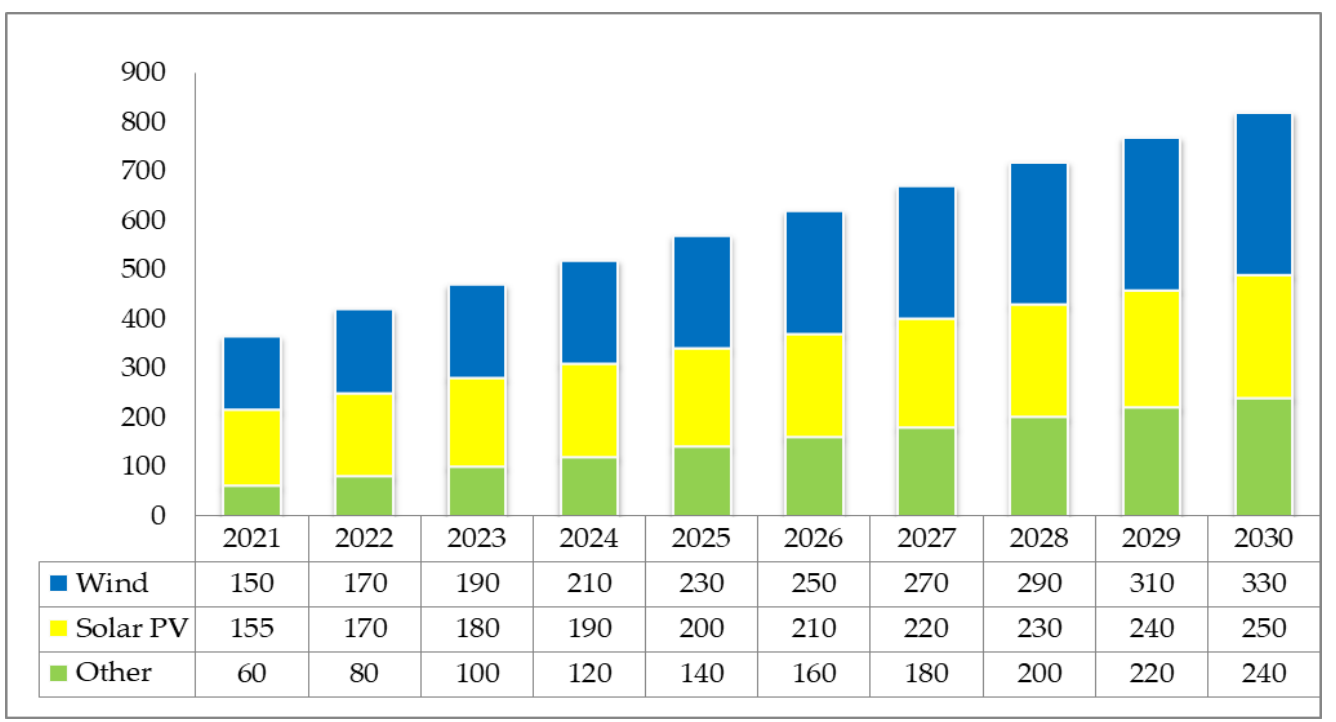

Figure 2. Projected capacity quotas (in MW) for renewable energy sources [30].

The employment factor method was used to assess the impact of decommissioning the solar and wind power plants on employment. A significant advantage of this method is its relative simplicity compared to other methods of job assessment (such as computable general equilibrium models and input-output analysis). It also has a fair number of assumptions and, together with its simplicity, these were the reasons to employ the method in the study undertaken. However, it has its limitations: it does not estimate how many jobs should be created in the transport sector or for research activities, and it does not allow us to estimate the employment in the subsequent recycling of the waste equipment. This approach is described in detail in [31]. The general methodology presumes that employment in the energy sector may facilitate equipment manufacturing, construction, installation, operation, and maintenance, the fuel supply, and decommissioning. In this study, we focus only on decommissioning, which can be expressed by the following formula:

$$
D=D(\text { year }) \times D E F \times R J M(\text { year })
$$

where $D$ (year $)$ = the amount of capacities decommissioned per year; $D E F=$ the decommissioning employment factor; and RJM (year) = the regional job multiplier per year [32] By the term "job", we mean one full-time employee. The decommissioning employment factors are 0.72 job-years/MW for wind power plants, and 1.21 job-years/MW for solar power plants [33]. One job in this article means 1 FTE (full-time equivalent), which is an average of $2080 \mathrm{~h}$, which is calculated according to the formula: $8 \mathrm{~h}$ a day $\times 5$ days a week $\times 52$ weeks a year. The regional job multiplier for Ukraine is assumed to be 1.08 for 2039-2059 [34]. 
This article reviews the legislation in the European Union, China, and Ukraine using the comparative approach. In particular, the following were examined: the provisions of Directive 2012/19/EU on the waste electric and electronic equipment [35]; the Package of the Circular Economy of the EU [36], the Decree on Waste Electric and Electronic Equipment 1 January 2011 of China [37]; the Law of Ukraine "On Waste" [38]; and The National Waste Management Strategy in Ukraine until 2030 [39]. The comparative approach allows for the determination of the best solutions for the country in focus, which, in this case, is Ukraine.

\section{Results and Discussion}

\subsection{Decommissioning Estimation}

This section aims to assess the amount of installed EOL equipment (solar and wind) to be decommissioned and the times of the waste streams. The data on the existing installed capacities of the solar PV and wind power plants in Ukraine were used to estimate the waste volumes. The capacities that should be decommissioned in 30 years for solar power plants [2], and in 25 years for wind power plants, are shown in Figure 3.

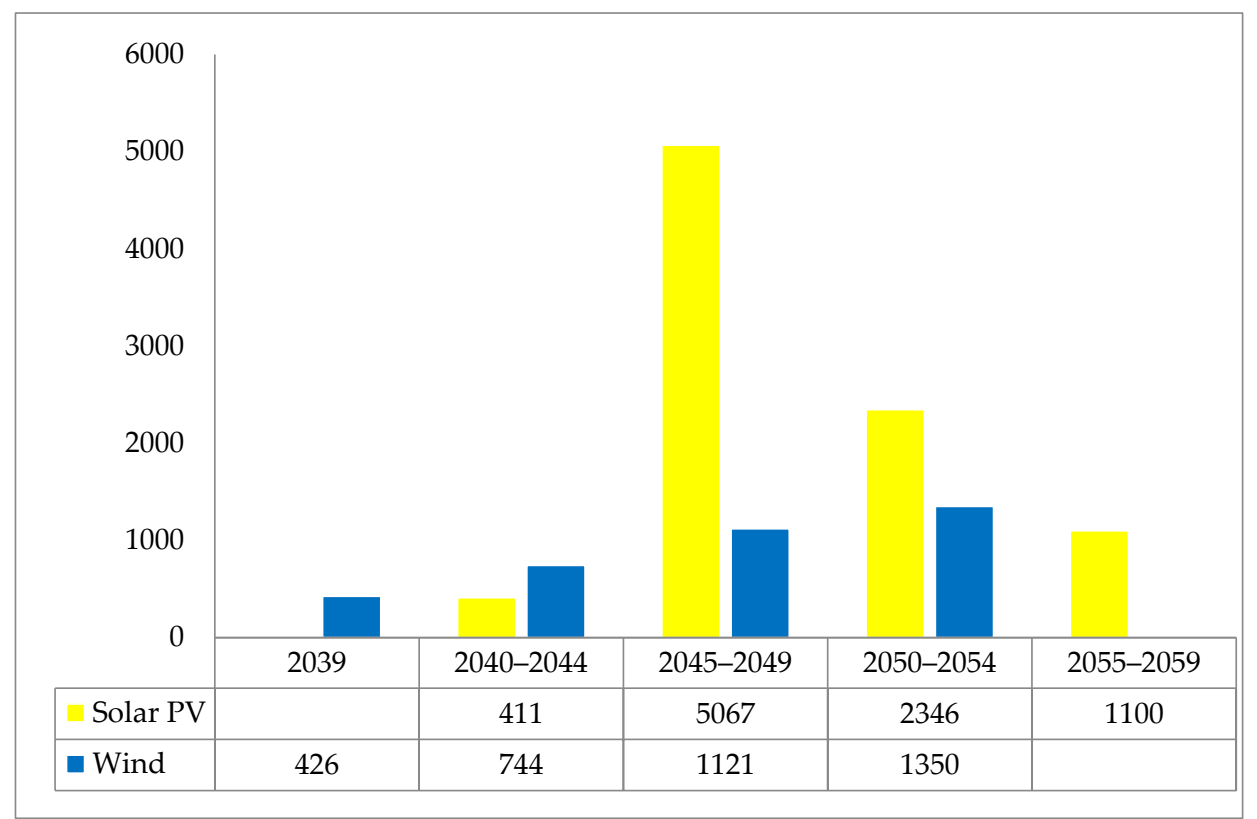

Figure 3. Decommissioning of solar and wind power plant capacities (in MW).

Figure 3 shows that the peak for decommissioning the panels is in 2049, which reflects a significant increase in the solar power plant capacity from 2019. An average ratio of the PV mass per unit capacity $(\mathrm{kg} / \mathrm{MW})$ was assessed by averaging the available data on the panel weight and the nominal power, which follows the IRENA and the IEA-PVPS [2] approaches. The weights of the constituent elements of the EOL crystalline silicon and the thin-film solar panels were calculated and are provided in Table 1.

Table 1. Compositions of elements in 1-MW capacity solar panels.

\begin{tabular}{cccccc}
\hline & Crystalline Silicon & & \multicolumn{2}{c}{ Thin-Film } \\
\hline Composition & Share & Weight, kg & Composition & Share & Weight, kg \\
\hline Glass & $71.0 \%$ & $57,687.5$ & Glass & $89.0 \%$ & $72,312.5$ \\
Aluminum & $8.0 \%$ & 6500 & Aluminum & $6.0 \%$ & 4875 \\
Copper & $1.0 \%$ & 812.5 & Plastic & $4.0 \%$ & 3250 \\
Silicon & $3.0 \%$ & 2437.5 & Metals & $1.0 \%$ & 812.5 \\
Silver & $0.1 \%$ & 81.25 & & & \\
Polymers & $12.0 \%$ & 9750 & & & \\
Other & $4.9 \%$ & 3981.25 & & & \\
\hline
\end{tabular}

Source: The authors' own calculations. 
From 2044 to 2059, approximately $8.9 \mathrm{GW}$ of solar power plants (Table 2), and 3.6 GW of wind power plants, should be decommissioned. In terms of recycling, this can produce significant amounts of secondary raw materials. In general, the processing of secondary raw materials is an essential element of the circular economy (reduce-reuse-recycle) and a deviation from the linear model of the economy in which raw materials are extracted, from which goods are produced and then discarded (take-make-dispose) [40]. According to the Circular Economy Finance Guidelines (2018) [41], the processing of EOL solar and wind equipment falls into several categories of the circular economy business models: Circular Inputs, when companies substitute raw materials with recycled materials, especially those from the recovery of materials and resources; Circular Design, when companies help to reduce the input of hazardous materials into the environment; and Resources Recovery, when companies recover value from waste, especially EOL waste. Projects that maintain the transition to the circular economy are expected to become more and more attractive for the financing sector; however, special policy instruments (such as taxation rebates) and financial de-risking instruments (such as loan guarantees and green bonds) need to be introduced and employed for countries with economies in transition [42].

Table 2. Compositions of raw materials (in 1000 tons) in solar PV power plants that should be decommissioned from 2044 to 2059.

\begin{tabular}{cccc}
\hline Composition & Crystalline Silicon & Thin-Film & Total \\
\hline Glass & 586.4 & 45.2 & 631.6 \\
Aluminum & 66.1 & 3.1 & 69.1 \\
Copper & 8.3 & & 8.3 \\
Silicon & 19.7 & & 19.7 \\
Silver & 0.7 & & 0.7 \\
Polymers & 78.8 & & 78.8 \\
Other & 52.3 & 2.0 & 52.3 \\
Plastic & & 2.0 \\
\hline
\end{tabular}

Source: The authors' own calculations.

To assess the feasibility of recycling EOL solar PV modules, we assume that the decommissioning cost for the ground-mounted modules is EUR 26,900/MW [10] (which is the vast majority in Ukraine, as rooftop installations are still insignificant). This corresponds to the IEA estimates that put the decommissioning cost at $5 \%$ of the construction cost [43]. We multiplied the solar PV waste stream, indicated in Figure 3, by the abovementioned decommissioning cost, and the results suggest that the overall decommissioning cost of solar PV modules reaches EUR 240.1 million.

For further calculations, we assume that, in terms of technology, the existing capacities of the solar PV plants in Ukraine comprise 7\% thin-film solar PV modules (by installed capacity), with the remainder as crystalline silicon [2] (bearing in mind that they were installed from 2010 to 2020, and that such a distribution corresponds to the technology development of that time).

The calculations are approximate, and it is worth noting that secondary raw materials, such as glass or aluminum, do not have to be recycled in the same year that they were collected and generated. Ukraine imports a large share of secondary raw materials from abroad because there is no operating system to collect such materials. The capacity of the domestic market of cullet (recycled glass) is 350-400 thousand tons/year, and the leading exporters are Belarus, Hungary, Lithuania, and the Republic of Moldova [44]. There are 16 cullet-processing plants in Ukraine [45]. Using cullet from decommissioned solar power plants in different years can amount to 3-58\% (in 2049) of the total market demand for cullet, or an average of about $10 \%$ of the annual demand. Every year, Ukraine imports cullet worth USD 1.5 million; in addition, glass can be recycled almost without waste, as it is possible to reuse $95 \%$ of glass [5]. Other materials are recycled at a rate of up to $70 \%$ by mass (IRENA) [2]; however, Dominguez and Geyer indicate a recycling rate of up to $92 \%$ using the best available technologies [6]. To estimate the market value of recovered 
materials, we multiply the amounts of recovered materials (using the recovery rate of 95\% for glass, and $70 \%$ for other materials) by the cost of the respective materials in 2021 prices. This approach has numerous flaws because of the high uncertainty of price fluctuations in the future, but it can still provide an idea of the value of the recycled materials. It can also indicate the amounts of materials that could replace the import without necessarily reducing the costs of these materials. With the cost of imported cullet in 2021 prices at UAH 0.00138 million/ $t$ [45], the market value of cullet from the decommissioned solar power plant is estimated to be EUR 26.8 million in Ukraine from 2044 to 2059.

Using a similar procedure, the market values of other recycled materials can be determined: with the cost of aluminum scrap in Ukraine at EUR 1300/t [46] in 2021 prices, the market value of aluminum from decommissioned solar power plants could be EUR 89.9 million from 2044 to 2059; the cost of copper scrap could be UAH 190,000/t [46], with a market value of EUR 50.6 million, from 2044 to 2059; and the cost of technical silver scrap could be EUR 387,000/t, with a market value of EUR 254.1 million, from 2044 to 2059. Consequently, the market values of cullet, aluminum, scrap copper, and technical silver from 2044 to 2059 upon the decommissioning of the solar power plants will amount to EUR 421.4 million in 2021 prices. Comparing the decommissioning cost of EUR 240.1 million to the potential cost of the recovered materials of EUR 421.4 million, one can state that recovering materials is feasible. However, particular business models and income flows require more precise calculations.

Later, we assess the feasibility of recycling EOL wind power plants. We assume that the decommissioning cost for an onshore wind power plant is EUR 13,490/MW [47], which corresponds to the IEA estimates that put the decommissioning cost at $5 \%$ of the construction cost [43]. We multiply the wind power plant waste stream (indicated in Figure 3) by the abovementioned decommissioning cost, which results in an overall decommissioning cost of EUR 49.1 million. Such a big contrast with the cost of decommissioning a solar PV plant can be explained by the significant dominance of solar PV installations in Ukraine. The compositions of the wind turbines are shown in Table 3.

Table 3. Compositions of raw materials (in tons) in wind power plants that should be decommissioned in Ukraine in from 2044 to 2059.

\begin{tabular}{|c|c|c|c|c|}
\hline Composition & $\begin{array}{l}\text { 50-MW Wind Park of } \\
\text { 2-MW Turbines }\end{array}$ & $\begin{array}{l}\text { 100-MW Wind Park of } \\
\text { 3.45-MW Turbines }\end{array}$ & Average per MW & $\begin{array}{l}\text { Raw Materials } \\
\text { in Total }\end{array}$ \\
\hline Concrete & $18,186.0$ & $54,169.92$ & 452.71 & $1,648,316$ \\
\hline Steel and iron & 6235.2 & $18,809.0$ & 156.40 & 569,441 \\
\hline Aluminum and alloys & 259.8 & 752.36 & 6.36 & 23,156 \\
\hline Copper and alloys & 259.8 & 0 & 2.60 & 9459 \\
\hline Polymer materials & 519.6 & 752.36 & 8.96 & 32,615 \\
\hline $\begin{array}{l}\text { Glass and carbon } \\
\text { composites }\end{array}$ & 519.6 & 752.36 & 8.96 & 32,615 \\
\hline Electronics & 0 & 0 & 0.00 & 0 \\
\hline Oil and coolants & 0 & 0 & 0.00 & 0 \\
\hline
\end{tabular}

Source: The authors' own calculations based on [48].

With the cost of secondary gravel (i.e., crushed concrete) in Ukraine at UAH 200/t (6.17 EUR/t) in 2021 prices [49], the market value of concrete from the decommissioned wind power plant is estimated to be EUR 10.2 million in Ukraine from 2044 to 2059. This recycled concrete could be used in road construction or drainage (i.e., it has areas of application). With the cost of a steel chip at UAH 1500/t (EUR46.3/t), the market value of recovered steel chip is EUR 26.4 million. The prices of aluminum and copper scrap were provided above; their market values from decommissioned wind power plants are estimated to be EUR 30.1 million and EUR 50.1 million, respectively, from 2044 to 2059. Polymer, glass, and composite materials are used to produce blades and nacelles, but currently, it is difficult to dismantle them. Electronics constitute less than $1 \%$ of a 
turbine mass and the controller consists of about 94,500 separate units [48]. We omit these materials to simplify the calculation because they might require high proficiencies to recover. Consequently, the market value of secondary gravel, scrap aluminum, scrap copper, and cullet from decommissioning wind power plants will amount to EUR 124.6 million in 2021 prices from 2044 to 2059. The assessment of the waste streams and the market values of the recovered materials coincide with the literature (IRENA [2] and Alsubal et al. [9]). However, Invernizzi et al. [10] indicate that the decommissioning assessments for RES are staggering as of 2020 .

Comparing the decommissioning cost of EUR 94.1 million to the potential cost of recovered materials of EUR 124.6 million, one can state that recovering materials is feasible.

Another alternative is the disposal of waste to existing industrial waste landfills (waste disposal sites). In 2021 prices, this service amounts to only EUR 6.8/t [40]. In nature, the decomposition period of glass is more than 1000 years; for aluminum, it is up to 500 years. As noted above, some components of solar and wind power plants are hazardous to the environment. In addition, the problem is intensified by the fact that there are many unauthorized landfills in Ukraine: as of 2019, there were more than 27,000. For legal entities, the fine for violating the established rules and the operating modes of installations and products from waste processing and disposal (landfills for storage or burial of industrial waste, as well as mixing or burial of waste, for the removal and disposal, of which there is an appropriate technology in Ukraine) without special permission from the central executive body amounts to only UAH 51-85 (EUR 1.6-2.7), which cannot stimulate an effective waste management system [40].

\subsection{Legislative Prerequisites}

For recycling solar and wind power plant waste equipment, the experience is most advanced in EU countries, where Directive 2012/19/EU on waste electric and electronic equipment is in place. This provides for an extended producer responsibility principle: that all equipment manufacturers are responsible for the collection, processing, and control of both the electric and electronic equipment sold in the European Union, regardless of the country in which it was manufactured. In other words, the manufacturer bears both the financial and organizational costs to eliminate its waste product. This directive was adopted to protect people and nature from toxic elements, including used electronics, and to reduce the burden of waste disposal costs, including from municipalities and local governments. Relevant secondary legislation has been developed (e.g., on methods for calculating the weight of waste formed in EU countries [50]; on the harmonization of the reporting formats for waste [51], etc.), and the provisions of the directive have been incorporated into national law by EU countries [52]. A standard for electronics waste, EN 50625, has been developed. In Germany, Stiftung EAR [53] has been operating since 2004, which registers solar panel manufacturers, and sets up financial aid to collect solar power plant EOL equipment and recycle it; the agency is funded by the Federal Ministry of the Environment, Nature Conservation and Nuclear Safety (BMU). In general, unprofitable extended responsibility organizations [53] are formed to implement the extended producer responsibility in practice. As of 2020, over 400 such organizations existed globally.

In the European Union in 2019, the final Package of the Circular Economy was adopted and approved for executing the Action Plan on the Circular Economy. These documents are the official basis for establishing the measures, criteria, and indicators of the circular economy. There are requirements for testing waste for harmful substances in the United States and Japan, and the recycling, reuse, or disposal methods should be identified [2].

China is a significant producer of photovoltaic and wind energy equipment. The Decree on Waste Electric and Electronic Equipment 1 January 2011 (an analogue of Directive 2012/19/EU) was adopted by the State Council in China, but it does not provide for the disposal of used solar panels. The Ministry of Environment of China compiles the list of goods for recycling, but this decree does not provide for liability in cases of the noncollection of waste, or for the measures and channels of collection [36]. Therefore, if 
equipment made in China is supplied to the European Union, there should be extended producer responsibility. If it is used in China, it is not necessary to recycle it.

In general, wind power and photovoltaic waste equipment is classified into general and industrial waste in most countries around the world. The turbines, towers, and blades of wind turbines are widely reused in other countries where renewable energy is only at the development stage.

According to the Waste Classifier of Ukraine, waste is considered to be " ... used, physically or morally worn-out ... materials that have lost their useful quality ... ; residual products of all other activities of enterprises, institutions, organizations and the population" [54]; thus, hereinafter, the EOL equipment of wind and solar power plants will be called wind and solar power plant "waste".

According to the Law of Ukraine "On Waste", companies have the right to "store the waste in specially designated places or facilities by sanitary standards and regulations of territory maintenance". Companies are obliged: to "determine the composition and properties of generated waste and the degree of waste hazard", "participate in the construction of waste management facilities", and carry out organizational and technological measures for maximum waste disposal; to ensure the sale or transfer to other consumers or companies, institutions, and organizations engaged in the collection, treatment, and disposal of waste; as well as to provide, at their own expense, the environmentally friendly recycling of waste that cannot be reused. Only companies with a waste generation index (WGI) of more than 1000 units are obliged to recycle waste. The WGI is calculated on the basis of the hazardous waste classification, but, as of 2021, no document defines the hazardous classes. Previously, the basis on which the type of waste danger was determined was DSanPiN 2.2.7.029-99 (State Sanitary Rules and Regulations), "Hygienic requirements for industrial waste management and determination of their hazardous class for the health of the population" [55], but its effect was terminated in 2014. Thus, currently, there is no immediate requirement to recycle wind and solar power plant waste in Ukraine.

The National Waste Management Strategy in Ukraine until 2030 (2017) and the National Waste Management Plan until 2030 (2019) [56] do not contain separate provisions that would relate to wind or solar power plant waste, and they also do not yet contain information on the potential waste equipment of wind and solar power plants. However, the Waste Management Strategy provides for introducing the principles of the circular economy in Ukraine. To implement the strategy, regional waste management programs have been developed (e.g., the Regional Industrial Waste Management Programme in the Donetsk region for 2018-2020) [57].

The main document allowing the Ukrainian legislation to approach the European legislation is the Association Agreement between the European Union and its Member States (one part) and Ukraine (the other part), 2014. However, the agreement does not provide for the implementation of Directive 2012/19/EU. Despite this, Ukraine has developed a draft law (No. 2350) on waste electrical and electronic equipment [58]; however, as of December 2021, it has not been adopted. There are National Standards of Ukraine (DTSU) for the following: solar panels (DSTU 8328: 2015 Solar Energy); PV modules (DSTU 8635: 2016 Solar Energy); and sites for PV plants (11 for wind energy) (DSTU 7338: 2013; DSTU 48 3896: 2007, etc.). There are also four Organizational Standards of Ukraine (SOU), including SOU-N MPP 27.180-66: 2006 and SOU-N EE 40.1-00100227-101: 2014; however, none of these contain recycling or disposal regulations.

The already installed equipment in Ukraine that needs to be decommissioned from 2040 to 2050 (Figure 3) does not qualify for extended producer responsibility. It needs to be decommissioned and, preferably, recycled without relying on China. If extended producer responsibility is applied to China, then the upfront cost of the produced equipment will be higher. This means that competition with other equipment manufacturers (including Ukrainian manufacturers) will be less fierce and may bring benefits to Ukrainian, or other, manufacturers. However, this issue requires further study. 
There is already experience in the disposal of used solar panels in Ukraine (and the replacement of second-hand solar panels), and all of the disposal costs are borne by the solar power plant owner (Scatec).

\subsection{Impact on Employment}

One can assess the impact on employment of the need to decommission solar and wind power plants at their EOL on the basis of two approaches:

(1) Decommissioning of equipment with subsequent recycling of waste equipment;

(2) Decommissioning of equipment without further recycling.

According to the first approach, many jobs can be created, including in physical repairs, the reuse of equipment, the further disposal of waste equipment, as well as administrative positions to manage the waste management process and research. According to the second approach, there is a need for people to decommission the equipment (i.e., technicians), crane operators, drivers to take the waste to landfills, and people to return the site to its original state. According to the IRENA, as of 2017, for decommissioning a wind farm with a capacity of $50 \mathrm{MW}$, the most labor-intensive activity was dismantling the equipment; both the site cleaning and the equipment disposal were significantly less labor intensive [59]. For decommissioning a solar power plant with a capacity of $50 \mathrm{MW}$, the most labor-intensive activity was the disassembly of the equipment, again with the equipment disposal and site cleaning being significantly less labor intensive [60].

The results of the calculations presented in Figure 4 show that most jobs for decommissioning will accrue from 2049 to 2050, which again reflects a significant increase in the installation of the solar power plant capacity from 2019 to 2020. From 2044 to 2059, for the decommissioning of the solar power plants, a total of 11,600 jobs could be involved, or an average of 729 jobs per year. For wind power plants, this figure is significantly lower-a total of 2800 jobs, or an average of 177 jobs per year.

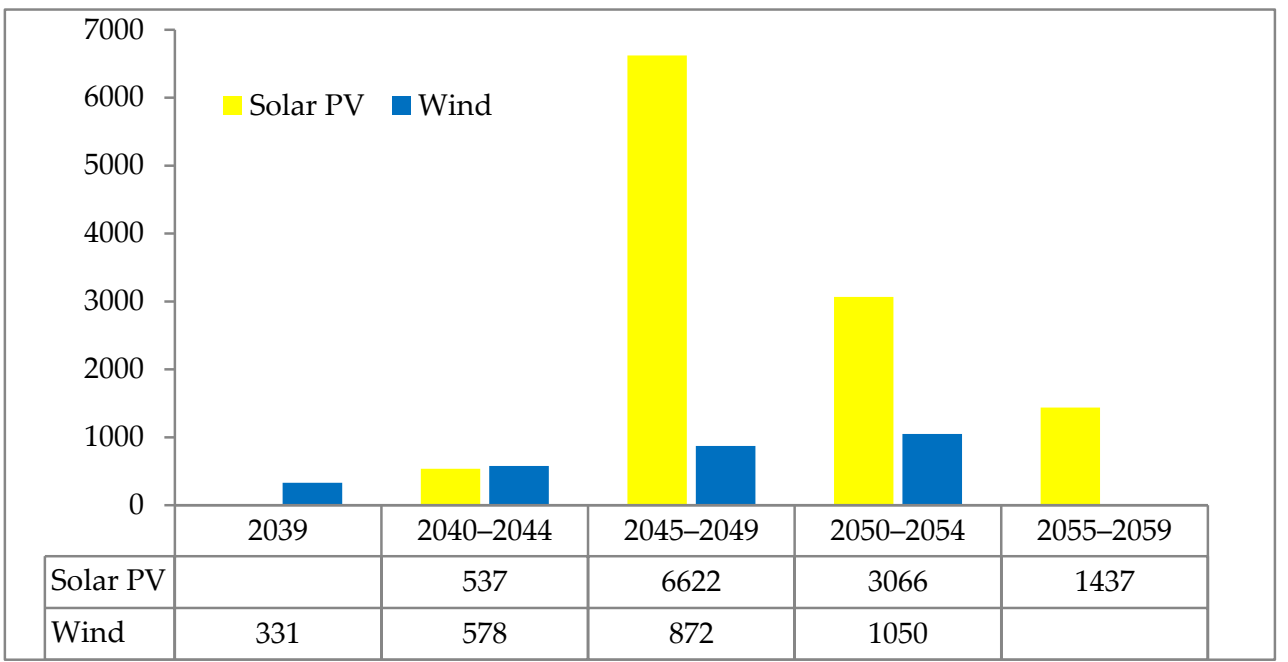

Figure 4. Employment (numbers of jobs) involved in decommissioning of solar and wind power plants in Ukraine.

\section{Conclusions}

In Ukraine, the significant capacities of wind and solar power plants have already been installed. These plants will eventually need to be decommissioned, regardless of how the renewable energy policy develops in the future. There are several options for managing wind and solar power plant waste equipment, notably, decommissioning without further recycling (i.e., removal to landfills), and decommissioning with the subsequent recycling of the resulting waste. The latter approach is the most advanced in terms of environmental 
protection, but it can also provide some economic benefits because the waste equipment consists of elements with market value.

So far, there is no regulatory framework in Ukraine that would stimulate the owners of solar and wind farms to send the received raw materials for recycling. For this, it is necessary to introduce market prices for waste disposal in Ukraine. In addition, it is essential to extend the scope of Directive 2012/19/EU to Ukraine within the framework of the Association Agreement in order to introduce the principle of extended producer responsibility. The latter can be achieved relatively quickly—according to PricewaterhouseCoopers, this principle can be introduced in Ukraine in one or two years at the level of the central authorities. In this regard, the principle must be incorporated into domestic legislation. Furthermore, the close cooperation of local governments with extended producer responsibility organizations is required. It may also be advisable to create a department (e.g., as part of the State Energy Efficiency and Energy Saving of Ukraine) where it would be possible to keep a register of all RES-based energy equipment. Furthermore, regional programs for the management of industrial waste should include provisions on the waste from wind and solar power plants. In particular, in the future: lists of enterprises should be developed where the waste equipment could appear; the types and classes of waste equipment should be assessed as industrial waste; and a list of disposal sites should be determined for the recycling of industrial waste. Additionally, it is necessary to adopt a normative legal act that would decide on the classifications of hazardous waste, which would make it possible to determine the hazard classes of solar and wind power plant waste equipment; this, in turn, would impose (or release) liability on the owners of wind and solar power plants for the recycling and/or disposal of equipment.

As of early 2022, the decommissioning of solar and wind power plants in Ukraine has not been actively discussed. The decommissioning of the currently installed wind and solar power plants in Ukraine will peak from 2049 to 2051. The market value of materials recovered from EOL solar PV modules from 2044 to 2059 could reach EUR 421.4 million in 2021 prices. Similarly, the market value of some recovered materials from EOL wind power plants from 2044 to 2059 could reach EUR 124.6 million in 2021 prices. The decommissioning and materials recovery for both EOL solar PV and wind power plants in Ukraine has proved feasible. Furthermore, the decommissioning of solar and wind power plants will ensure 14,500 jobs, or an average of 450 jobs per year.

Author Contributions: Conceptualization, G.T. and T.K.; methodology, G.T.; software, Y.K.; validation, H.H. and O.P.; formal analysis, H.H. and O.P.; writing-original draft preparation, G.T.; writing-review and editing, G.T., T.K. and H.H.; supervision, G.T.; project administration, O.P. All authors have read and agreed to the published version of the manuscript.

Funding: This research was funded by the National Academy of Science of Ukraine in the framework of the research project: "The Harmonized Policy for the Development of Energy Markets of Ukraine and the EU in the context of the European Green Deal". The APC was funded by the University of Bielsko-Biala.

Informed Consent Statement: Informed consent was obtained from all subjects involved in the study.

Conflicts of Interest: The authors declare no conflict of interest.

\section{References}

1. IEA. Net Zero by 2050. A Roadmap for the Global Energy Sector; International Energy Agency: Paris, France, 2021.

2. IRENA; IEA-PVPS. End-of-Life Management: Solar Photovoltaic Panels; International Renewable Energy Agency and International Energy Agency Photovoltaic Power Systems: Abu Dhabi, United Arab Emirates, 2016.

3. Ndzibah, E.; Pinilla-De La Cruz, G.A.; Shamsuzzoha, A. End of life analysis of solar photovoltaic panel: Roadmap for developing economies. Int. J. Energy Sect. Manag. 2021. Available online: https://www.emerald.com/insight/content/doi/10.1108/IJESM11-2020-0005/full/pdf?title=end-of-life-analysis-of-solar-photovoltaic-panel-roadmap-for-developing-economies (accessed on 15 September 2021). [CrossRef]

4. Markert, E.; Celik, I.; Apul, D. Private and Externality Costs and Benefits of Recycling Crystalline Silicon (c-Si) Photovoltaic Panels. Energies 2020, 13, 3650. [CrossRef] 
5. Chowdhury, S.; Rahman, K.S.; Chowdhury, T.; Nuthammachot, N.; Techato, K.; Akhtaruzzaman, M.; Kiong Tiong, S.; Sopian, K.; Amin, N. An overview of solar photovoltaic panels' end-of-life material recycling. Energy Strategy Rev. 2020, $27,100431$. [CrossRef]

6. Domínguez, A.; Geyer, R. Photovoltaic waste assessment in Mexico. Resour. Conserv. Recycl. 2017, 127, 29-41. [CrossRef]

7. Mathur, D.; Gregory, R.; Simmons, T. End-of-life Management of Solar PV Panels. 2020. Available online: https:/ /www.cdu.edu. $\mathrm{au} /$ sites/default/files/the-northern-institute/eolmanagemnetsolarpv_final_e-version.pdf (accessed on 31 January 2022).

8. Lunardi, M.M.; Alvarez-Gaitan, J.P.; Bilbao, J.I.; Corkish, R. Comparative Life Cycle Assessment of End-of-Life Silicon Solar Photovoltaic Modules. Appl. Sci. 2018, 8, 1396. [CrossRef]

9. Alsubal, S.; Alaloul, W.S.; Shawn, E.L.; Liew, M.S.; Palaniappan, P.; Musarat, M.A. Life Cycle Cost Assessment of Offshore Wind Farm: Kudat Malaysia Case. Sustainability 2021, 13, 7943. [CrossRef]

10. Invernizzi, D.C.; Locatelli, G.; Velenturf, A.; Love, P.E.; Purnell, P.; Brookes, N.J. Developing policies for the end-of-life of energy infrastructure: Coming to terms with the challenges of decommissioning. Energy Policy 2020, 144, 111677. [CrossRef]

11. Pimonenko, T.; Prokopenko, O.; Dado, J. Net zero house: EU experience in Ukrainian conditions. Int. J. Ecol. Econ. Stat. 2017, 38, 46-57.

12. GreenMatch. The Opportunities of Solar Panel Recycling. Available online: https://www.greenmatch.co.uk/blog/2017/10/theopportunities-of-solar-panel-recycling (accessed on 15 September 2021).

13. ROSI. Recycling PV Modules. Market, Legal, and Technical Perspectives. Available online: https://cutt.ly/SxAwKVE (accessed on 15 September 2021).

14. Maleki, A.; Pourfayaz, F.; Ahmadi, M.H. Design of a cost-effective wind/photovoltaic/hydrogen energy system for supplying a desalination unit by a heuristic approach. Sol. Energy 2016, 139, 666-675. [CrossRef]

15. Ahmadi, M.H.; Hosseini Dehshiri, S.S.; Hosseini Dehshiri, S.J.; Mostafaeipour, A.; Almutairi, K.; Ao, H.X.; Rezaei, M.; Techato, K. A Thorough Economic Evaluation by Implementing Solar/Wind Energies for Hydrogen Production: A Case Study. Sustainability 2022, 14, 1177. [CrossRef]

16. LMWindPower. ZEBRA. Available online: https://www.lmwindpower.com/en/stories-and-press/stories/news-from-lm-plac es/zebra-project-launched (accessed on 15 September 2021).

17. RenEn. Old Wind Turbine Blades as Raw Material for Cement. Available online: https://renen.ru/starye-lopasti-vetrogenerator ov-v-kachestve-syrya-dlya-tsementa/?fbclid=IwAR0krgABacPuKr-szsJpotqLITx-oZK4iVmcHegRyzhdJbL2_GW7LPc4-SI (accessed on 15 September 2021).

18. Euronews. Recycling Turbine Blades: The Achilles Heel of Wind Power. 2021. Available online: https://www.euronews.com/m y-europe/2021/06/25/recycling-turbine-blades-the-achilles-heel-of-wind-power-and-the-controversy-engulfing-ren (accessed on 15 September 2021).

19. Nykyruy, L.; Yakubiv, V.; Wisz, G.; Hryhoruk, I.; Oleksyn, Z.; Yavorsky, R. Renewable Energy in Ukraine-Poland Region: Comparison, Critical Analysis, and Opportunities. Renew. Energy-Resour. Chall. Appl. 2020. [CrossRef]

20. Kharlamova, G.; Nate, S.; Chernyak, O. Renewable energy and security for Ukraine: Challenge or smart way? J. Int. Stud. 2016, 9 , 88-115. [CrossRef] [PubMed]

21. Kolosok, S.; Myroshnychenko, I.; Zakharkina, L. Open Data in Electrical Energy Balancing of Ukraine: Green Deal and Security Aspects. CEUR Workshop Proceedings. In Proceedings of the 16th International Conference on ICT in Education, Research and Industrial Applications. Integration, Harmonization and Knowledge Transfer. Volume II: Workshops (ICTERI 2020), Kharkiv, Ukraine, 6-10 October 2020; Sokolov, O., Zholtkevych, G., Yakovyna, V., Tarasich, Y., Kharchenko, V., Kobets, V., Burov, O., Semerikov, S., Kravtsov, H., Eds.; 2020. Available online: http:/ / ceur-ws.org/Vol-2732/20200270.pdf (accessed on 1 December 2021).

22. Agapova, O.; Popovych, N.; Shulika, B.; Peresadko, V.; Fylenko, V. Research of the spatial aspects of using renewable energy sources for sustainable development of the territory. Technol. Audit. Prod. Reserves 2018, 6, 50-58. [CrossRef]

23. Child, M.; Breyer, C.; Bogdanov, D.; Fell, H.-J. The role of storage technologies for the transition to a $100 \%$ renewable energy system in Ukraine. Energy Procedia 2017, 135, 410-423. [CrossRef]

24. Kuzior, A.; Lobanova, A.; Kalashnikova, L. Green Energy in Ukraine: State, Public Demands, and Trends. Energies 2021, 14, 7745. [CrossRef]

25. CMU. On approval of the Renewed Nationally Determined Contribution of Ukraine to the Paris Agreement. Order of the Cabinet of Ministers of Ukraine Dated 30 July, 2021 \#868-p. 2021. Available online: https://zakon.rada.gov.ua/laws/show/868-2021-p\#T ext (accessed on 19 November 2021).

26. CMU. On Approval of the National Economic Strategy for the Period up to 2030. Decree of the Cabinet of Ministers of Ukraine Dated 3 March, 2021 \#179. 2021. Available online: https:/ / zakon.rada.gov.ua/laws/show/179-2021-\%D0\%BF (accessed on 19 November 2021).

27. State Agency on Energy Efficiency and Energy Saving of Ukraine. Available online: https://saee.gov.ua/uk/news/3930 (accessed on 15 September 2021).

28. Nechyporenko, D. Webinar «Solar PV Waste Management in Ukraine». EUEA. Personal Communication. 25 March 2021. Available online: https:/ / euea-energyagency.org/en/news/market-news/solar-pv/ (accessed on 15 September 2021).

29. EPA. Silver. EPA R.E.D. Facts. United States Environmental Protection Agency. 1993. Available online: https://www3.epa.gov/p esticides/chem_search/reg_actions/reregistration/fs_G-75_1-Jun-93.pdf (accessed on 19 November 2021). 
30. Let's Save Electricity. Available online: https://letsavelectricity.com/what-is-the-size-of-a-solar-panel-weight-of-a-solar-panel/ (accessed on 15 September 2021).

31. Low Carbon Ukraine. Reaching Ukraine's Energy and Climate Targets. G. Zachmann (editor). Low Carbon Ukraine, BE Berlin Economics GmbH, German Federal Ministry for the Environment, Nature Conservation and Nuclear Safety. 2021. Available online: https://www.lowcarbonukraine.com/en/reaching-ukraines-energy-and-climate-targets/ (accessed on 19 September 2021).

32. Rutovitz, J.; Dominish, E.; Downes, J. Calculating Global Energy Sector Jobs: 2015 Methodology; Prepared for Greenpeace International by the Institute for Sustainable Futures; University of Technology Sydney: Ultimo, NSW, Australia, 2015.

33. Ram, M.; Aghahosseini, A.; Breyer, C. Job creation during the global energy transition towards $100 \%$ renewable power system by 2050. Technol. Forecast. Soc. Chang. 2020, 151. [CrossRef]

34. Trypolska, G. Prospects for employment in renewable energy in Ukraine, 2014-2035. Int. J. Glob. Energy Issues 2021, 43, $436-457$. [CrossRef]

35. Directive 20212/19/EU On Waste from Electrical and Electronic Equipment (WEEE). Available online: https:/ / ec.europa.eu/env ironment/topics/waste-and-recycling/waste-electrical-and-electronic-equipment-weee_en (accessed on 15 September 2021).

36. Report from the Commission to the European Parliament, the Council, the European Economic and Social Committee and the Committee of the Regions on the Implementation of the Circular Economy Action Plan. COM/2019/190 Final. Available online: https: / / eur-lex.europa.eu/legal-content/EN/TXT/ ?qid=1551871195772\&uri=CELEX:52019DC0190 (accessed on 15 September 2021).

37. Lu, C.; Zhang, L.; Zhong, Y.; Ren, W.; Tobias, M.; Mu, Z.; Ma, Z.; Geng, Y.; Xue, B. An overview of e-waste management in China. J. Mater. Cycles Waste Manag. 2015, 17, 1-12. [CrossRef]

38. Law of Ukraine. “On Waste” No 187/98-VR Dated 05 March 1998. Available online: https://zakon.rada.gov.ua/laws/show/18 7/98-Bp\#Text (accessed on 15 September 2021).

39. Order of the Cabinet of Ministers Dated 8 November 2017 No 820-p «On Approval of The National Waste Management Strategy in Ukraine». Available online: https:/ / zakon.rada.gov.ua/laws/show /820-2017-p\#Text (accessed on 15 September 2021).

40. From the Third World to the First. Waste Management Reform in Ukraine; Price Waterhouse Coopers: London, UK, 2020.

41. Circular Economy Finance Guidelines (2018) ABN AMRO, ING, RABOBANK. Available online: https://u.to/0w61Gw (accessed on 28 October 2021).

42. Schröder, P.; Raes, J. Financing an Inclusive Circular Economy. De-Risking Investments for Circular Business Models and the SDGs. Chatham House. 2021. Available online: https://www.chathamhouse.org/sites/default/files/2021-07/2021-07-16-inclus ive-circular-economy-schroder-raes_0.pdf (accessed on 28 October 2021).

43. Projected Costs of Generating Electricity. International Energy Agency, Nuclear Energy Agency, Organisation for Economic Co-Operation and Development. 2010. Available online: http://www.iea.org/textbase/nppdf/free/2010/projected_costs.pdf (accessed on 31 January 2022).

44. Dilo. Ukrainian Glass Producers Have Stopped Working Due to Gas Prices. 2020. Available online: https://dilo.net.ua/novyny /ukrayinski-vyrobnyky-skla-zupynyly-robotu-cherez-tsiny-na-gaz/ (accessed on 15 September 2021).

45. Rikhlitskiy, V. Ukraine Imports Waste from Other Countries for Billions. Why and How Do We Have a Waste Recycling Business. Available online: https:/ /www.epravda.com.ua/rus/publications/2021/06/18/675131/ (accessed on 15 September 2021).

46. Scrap Metal Purchase Center “Ukr Lom”. 2021. Available online: https://www.reclamet.co.uk/scrap-metal-prices (accessed on 31 January 2022).

47. Ortegon, K.; Nies, L.F.; Sutherland, J.W. Preparing for end of service life of wind turbines. J. Clean. Prod. 2013, 39, 191-199. [CrossRef]

48. Carrara, S.; Alves Dias, P.; Plazzotta, B.; Pavel, C. Raw Materials Demand for Wind and Solar PV Technologies in the Transition towards a Decarbonised Energy System; EUR 30095 EN; Publications Office of the European Union: Luxembourg, 2020. [CrossRef]

49. Industrial Marketplace of Ukraine. 2022. Available online: https://prom.ua/Vtorichnyj-scheben-droblyonyj-beton.html (accessed on 31 January 2022).

50. Commission Implementing Regulation (EU) 2017/699 of 18 April 2017 Establishing a Common Methodology for the Calculation of the Weight of Electrical and Electronic Equipment (EEE) Placed on the Market of Each Member State and a Common Methodology for the Calculation of the Quantity of Waste Electrical and Electronic Equipment (WEEE) Generated by Weight in Each Member State. Available online: https:/ / eur-lex.europa.eu/legal-content/EN/TXT/?uri=CELEX:32017R0699 (accessed on 15 September 2021).

51. Commission Implementing Regulation (EU) 2019/290 of 19 February 2019 Establishing the Format for Registration and Reporting of Producers of Electrical and Electronic Equipment to the Register. Available online: https:/ / eur-lex.europa.eu/legal-content/ EN/TXT/?uri=uriserv:OJ.L_.2019.048.01.0006.01.ENG\&toc=OJ:L:2019:048:TOC\%20) (accessed on 15 September 2021).

52. Miśkiewicz, R. The Importance of Knowledge Transfer on the Energy Market. Polityka Energetyczna 2018, 21, 49-62. [CrossRef]

53. Stiftung EAR. Available online: https:/ / www.stiftung-ear.de/de/ueber-uns/wer-wir-sind (accessed on 15 September 2021).

54. State Classifier of Ukraine. Waste Classifier ДК 005-96. Available online: https:/ / zakon.rada.gov.ua/rada/show/v0089217-96\# Text (accessed on 15 September 2021). 
55. DSanPiN 2.2.7.029-99. Hygienic Requirements for Industrial Waste Management and Determination of Their Hazardous Class for the Health of the Population. Available online: https://zakon.rada.gov.ua/rada/show/v0029588-99?lang=ru\#Text (accessed on 15 September 2021).

56. Order of the Cabinet of Ministers Dated 20 February 2019 No 117-p “On Approval of the National Waste Management Plan until 2030". Available online: https:/ / www.kmu.gov.ua/npas/pro-zatverdzhennya-nacionalnogo-planu-upravlinnya-vidhodamido-2030-roku (accessed on 15 September 2021).

57. Regional Program for Industrial Waste Management in Donetsk Region for 2018-2020. Available online: http:/ / ecology.donoda.g ov.ua/wp-content/uploads/2019/05/PO \%D0\%97\%D0\%9FOP \%D0\%AF\%D0\%94\%D0\%96EHH \%D0\%AF- \%E2\%84\%96-1580 pdf (accessed on 15 September 2021).

58. Draft Law on Waste Electrical and Electronic Equipment No 2350 dated 30 October 2019. Available online: http://w1.c1.rada.gov .ua/pls / zweb2/webproc4_1?pf3511=67234 (accessed on 15 September 2021).

59. IRENA. Renewable Energy Benefits: Leveraging Local Capacity for Onshore Wind; International Renewable Energy Agency: Abu Dhabi, United Arab Emirates, 2017.

60. IRENA. Renewable energy benefits: Leveraging local capacity for solar PV; International Renewable Energy Agency: Abu Dhabi, United Arab Emirates, 2017. 